\title{
Plano de Assistência
}

Dois trabalhos de incalculàvel importância que muito credenciam a administração de pessoal no Brasil são o Plano de Classificação de Cargos e o Plano de Assistência aos Servidores Públicos Civis da União. Do primeiro já se sabe o que foi realizado, cabendo, no momento, ao Congresso Nacional ultimar o projeto de lei em que se consubstancia.

A respeito do Plano de Assistência pouco foi divulgado. Muitas criticas têm surgido face à demora com que os estudos se processam. Emprêsa de tal envergadura não poderia, realmente, ultimar-se contando apenas com a boa intenção dos seus planejadores. Muitas etapas teriam de ser vencidas, muitas pesquisas haveriam de ser efetuadas, entre elas o levantamento real da situação existente.

Dentre as maiores dificuldades ressalta, porém, a que se relaciona com as disponibilidades financeiras para ocorrer à efetivação das medidas que deverão ser postas em prática. Ninguém ignora a gravidade da conjuntura econômicr em todos os setores do Pais. Tal estado de coisas há de se refletir, necessuriamente, nos programas administrativos que ao govêrno incumbe elaborar. Entretanto o elemento humano empregado no serviço público não pode prescindir das instituições de assistência, nas quais busca a satisfação das suas necessidades imediatas ou futuras, e o não atendimento dos seus problemas, resultará em colocá-lo num estado de espírito indesejavel, frustrando-lhe preciosas energias morais, com visivel prejuizo para o exercício das atribuições que desempenha e, conseqüentemente, para a organização a que serve.

A assistência ao pessoal, objetivando o seu bem-estar, não deve ter o caráter magnânimo de caridade politica. Decorre de lei. É, portanto, um dever do Estado moderno, re- 
sultante do reconhecimento de que o rendimento do empregado aumenta quando se sente protegido em relação a si próprio e à sua familia. A finalidade da assistência não reside, contudo, tão só no aumento do rendimento, mas tem especialmente em mira o ser humano, que acima de tudo deve receber amparo do Estado. Dai, uma conseqüência de alto sentido para a administração de pessoal: a elevação do moral da organização, problema que não poderá ser descurado pelo administrador técnica e teóricamente preparado. Neste sentido é que Lewis Meriam esclarece: "É certo que o govêrno tanto tem interêsse como responsabilidade na segurança de seus empregados, e na manutencão de con. dições de trabalho sanitárias e higiênicas. Tem enorme interêsse financeiro por qualquer trabalho médico preventivo. que diminua o tempo perdido com acidentes e moléstias".

O bem estar pessoal, econômico e espiritual, constituem a base do sistema que se procura instituir.

A Lei n. 1.711, de 28 de outubro de 1952 (Estatuto), no seu art. 160 determinou: "A União prestará assistênciut "ao funcionário e à sua família".

A mesma lei, no seu art. 161, revela a extensão e a natureza do sistema que se deverá pôr em prática, fazendo-o compreender a assistência médica, hospitalar e a rêde de creches; previdência, seguro e assistência judiciária. Outros dos seus aspectos proeminentes relacionam-se com a espe. cialização profissional do servidor, e o aperfeiçoamento moral e intelectual dos mesmos e de suas familias. A grande novidade do plano, prevista no art. 256 da mencionada Lei n. 1.711, consiste, todavia, no minimo que assegura, de $45 \%$, do vencimento ou remuneração do funcionário, "como base da pensão à sua família". Tal inovação revela um sentido avancado de previdência, ocasionaindo a natural inquietacão de parte dos servidores, ansiosos por ver consignado em dispositivo legal as novas e salutares medidas projetadas. Maior é ainda a inquietude por ter estabelecido, o art. 256 do Estatuto, que "as medidas para a execução do plano" deveriam ser promovidas "dentro do prazo de 12 meses". 
Fôrça é convir, no entanto, que a elaboração de trabatho de tal amplitude e responsabilidade não poderá ser levado a efeito fácilmente, não sendo justo, por conseguinte, inculcar-se de negligência ao Poder Executivo, quando, além do mais, outros problemas existem que não dependem do seu arbitrio. Traçadas, porém, as linhas mestras do sistema e alcançados os meios de concretizar o Plano de Assistência, o funcionalismo da União terá conseguido nova e significativa vitória que, juntamente com o Plano de Classificação de Cargos, the dará posição de relêvo, contribuindo para elevar o prestigio, tantas vêzes mal reconhecido, da função pública.

A mentalidude fragmentária da administração dos negócios públicos, graças à visão sempre parcial dos problemas sociais, tem dado ensejo a que providências isoladas sejam transformadas em leis, destituídas, porém, do senso de conexão e de continuidade.

Rubens da Rocha Paranhos - in R.S.P. junho de 1950. 